\title{
)
}

\section{オートバイアルスズコロイド（ダイナボット社）に関する基礎実験 （主に硫黄コロイドとの比較）}

\author{
北海道大学医学部付属病院放射線部（部長 入江五朗） \\ 鈴木幸太郎・过宏小小川善辢

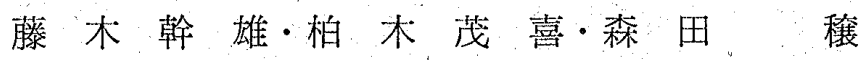 \\ （受付 昭和49年 6 月 13 日）
}

(Code No. 32234)

A STUDY ON 'AUTOVIAL Sn-COLLOID'
By Kotaro Suzuki
HIROSHI TSUJI
YOSHITERU OGAWA
MIKIO FUJIKI
SHIGEYOSHI KASHIWAGI
YUTAKA MORITA
Department of Radiology, Hokkaido University Hospital. (Director : GORO IRIE)

(Article received; Jun. 13, 1974)

\section{Summary}

Sn-Colloid made by means of "AUTOVIAL" developed by DINABOT CO. was compared in several ways with S-Colloid which has been used routinely in many centers.

The results revealed the Sn-Colloid is at least no worse than S-Colloid from diagnostic point of view and is much better for safety of medical stuffs.

\section{1. 緒 言}

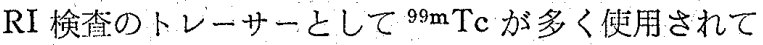
いる。その標識方法す各種開発されているが肝シンチグ

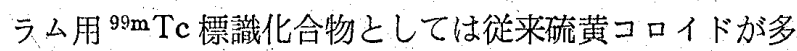
く用いられてきた。しかしその調整方法は加熱処理など 時閔が加かり簡易な方法とはいえない。
簡単な調整放として，ダイナボット社より市販され ているオートラベラーによる肝シンチグラム用オード゙ イアルスズコロイドについて硫黄コロイドとの比較など 二,三の検討を行ったので報告する。

\section{2. 使用装置および器具材料}

（1）ダイナボット社製オートラベラー，オートバイア 


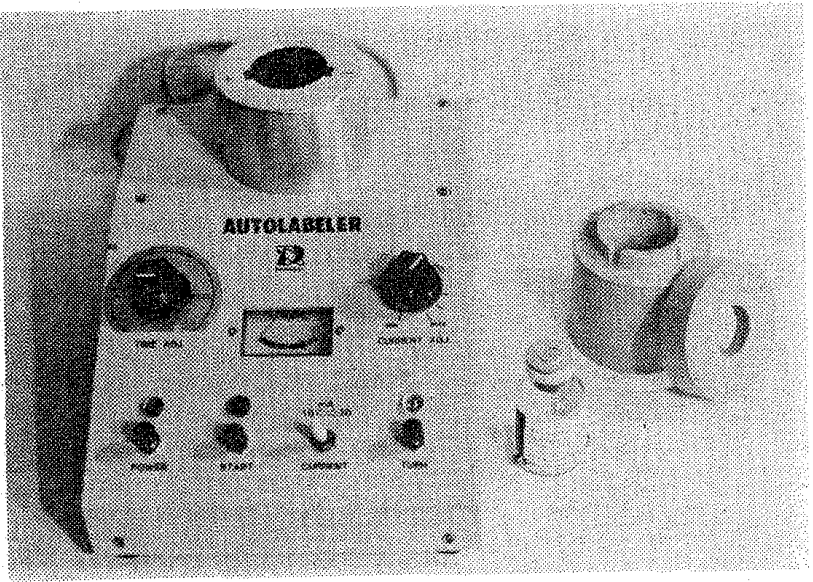

Fig. 1

ル, シールドケース. (Fig. 1)

(2) トーヨーメンブランフィルター（東洋ろ紙株式会 社製)

（3） $2 \mathrm{CH}$ 動態機能検查装置（島津製作所製）

$$
\begin{aligned}
& \text { ディチクター B-2018 } \\
& \text { スヘクトロメーター ES-7 } \\
& \text { レコーダー UR-220 }
\end{aligned}
$$

(4) ウェル型シンチレーションカウシター（神戸工業 製)

$$
\begin{aligned}
& \text { 検出器 PS- } 400 \\
& \text { スケーラー } 10 \mathrm{~T} 005 \\
& \text { タイマ- TM-2 }
\end{aligned}
$$

(5) Neuclear Chicago 製シンチカメラ

PHO/GAMMA III model 6403

(6) 電離槽型サーベイメーター（アロカ製）

(7) 硫黄コロイドキット（ダイナボット社製）

\section{3. 英踔方法}

(1) オートバイアルスズコロイドのフィルター非ろ過 率およびその経時変化

オートバイアルスズコロイドを $4 \mathrm{ml}$ 調整し $0.1 \mu の$ フィルターでとれをろ過した．万過する前のコロイト液 および，コロイド液をろ過したフィルターをウェル型シ ンチレーションカウンターて测定し，末ろ過萑化対する 非ろ過成分の剖合を求めてれを粒子サイズで $0.1 \mu$ 以上 のフィルター非ろ過率とした（以下「非ろ過率」とす ろ.)

との操作をオートバイアルスズコロイドはコロイド調 整後 5 分, 30 分, 1 時間, 2 時間, 3 時間, 4 時間, 5 時間， 6 時間飞ついて，又硫黄コロイドは 5 分，30分， 1.5時間，2.5時間，5.5時間について行い各時間の非ろ 過率を求めた。
(2)，調整量のちがいによる非ろ過率

調整量は $4 \mathrm{ml}$ 己指定されているか調整量と非ろ過率 の関係をみるために，オートバイアルスズコロイドを 2 $\mathrm{ml}, 4 \mathrm{ml}, 8 \mathrm{ml}, 10 \mathrm{ml}$ 調整し各々について調整後 30 分に

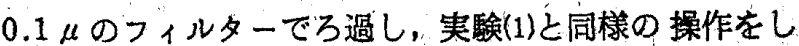
た.

(3）オートバィアルスズコロイドおよひ硫黄コロイド の体内分布

オートバイアルスズコロイドおよひ硫黄コロイドを用 いて肝シンチホトグラフィーを行う時 $2 \mathrm{CH}$ 動態機能検 查装置で肝部，左上肺部，左大腿部の計数を測定した。 静注量はオートバイアルスズコロイドについては1〜5 $\mathrm{m} l$, 硫黄コロイドは約 $2 \sim 10 \mathrm{ml}$ でいずれす $5 \mathrm{mCi}$ を时 静脈より静注したものである.検出器は内径 $5 \mathrm{~cm}$ の円

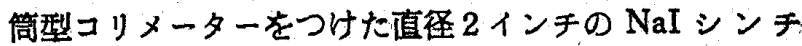
レーション検出器である.

肝部を $100 \%$ とした時の各部の割合（以下「掫取率」 とする.) を静注後 20 分加ら 1 時間の間で求めた。なお 盰部に関しては cps メーターが最高俌を示す部位の計数 を用いた。

（4）調整時間，被曝についての検討

調整時䦩について, ミルキングした ${ }^{99 \mathrm{~m}} \mathrm{TcO}_{4}$ - 溶液は 用意されているものとし特流黄コロイドの場合注誠整 汇必要な沸滕水もすで潐備されているすのとして調整 操作が完了するまでの時間を検討した。

調整時の被曝に関しては ${ }^{99 \mathrm{~m}} \mathrm{TcO}_{4}$ - 溶液 $20 \mathrm{mCi}$ (約 4 $\mathrm{m} l)$ を調整するあのとし，反応バイアルに ${ }^{99 \mathrm{~m}} \mathrm{TcO}_{4}$ - 溶 液を注入し終った時から調整操作が完了するまでの間 で西コロイドの比較をした．测定には電離槽型サーべイ メーターを使用しフルスケール $1 \mathrm{mR} / \mathrm{hrs}$ の線量率值を 用いた. 雨コロイドとも測定器から反応バイアルまでの 距離は $50 \mathrm{~cm}$, 反応バイアルの入ったシールドケースを 測定器方向へ $45^{\circ}$ 傾りた状的で測定した。

なおオートバイアルスズコロイドの専用シールドケ 一スは、材質はレイテナーで厚さ $15 \mathrm{~mm}$ (Fig. 1)，硫黄 コロイド用ケースは厚さ $4 \mathrm{~mm}$ の鉛䌘ヶースである。

\section{4. 宽䠝結果}

(1) コロイドのフィルター非ろ過率およびその経時変 化

オートバイアルスズコロイドおよび硫黄コロイドの非 ろ過率の経時変化は Fig. 2 亿示した. 硫黄コロイドでは 調整後2.5時間まではほほ99\%のの非ろ過率で，5.5時間後 では96.3\%となる。一方オートバイアルスズコロイドの 


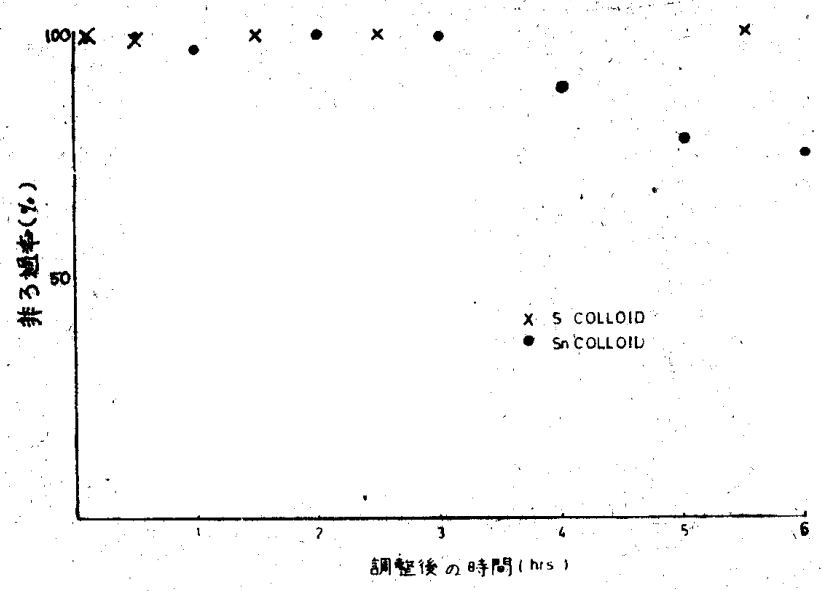

Fig. 2 非万過率の経時変化

非ろ過率は調整後 3 時間までは硫黄コロイドと同㥞にほ ほ99\%である. しかし 3 時間後では非ろ過率は低下する 傾向にあり，調整後 6 時間では74.9\%になる.

（2）調整量のちがいによる非ろ過率

Fig. 3 は調整量のちがいによる非ろ過率で調整量 $8 \mathrm{~m} l$ まではほほ $99 \%$ の非ろ過率で調整量 $10 \mathrm{ml}$ では $2 \%$ 位非 ろ過率泜くなる。

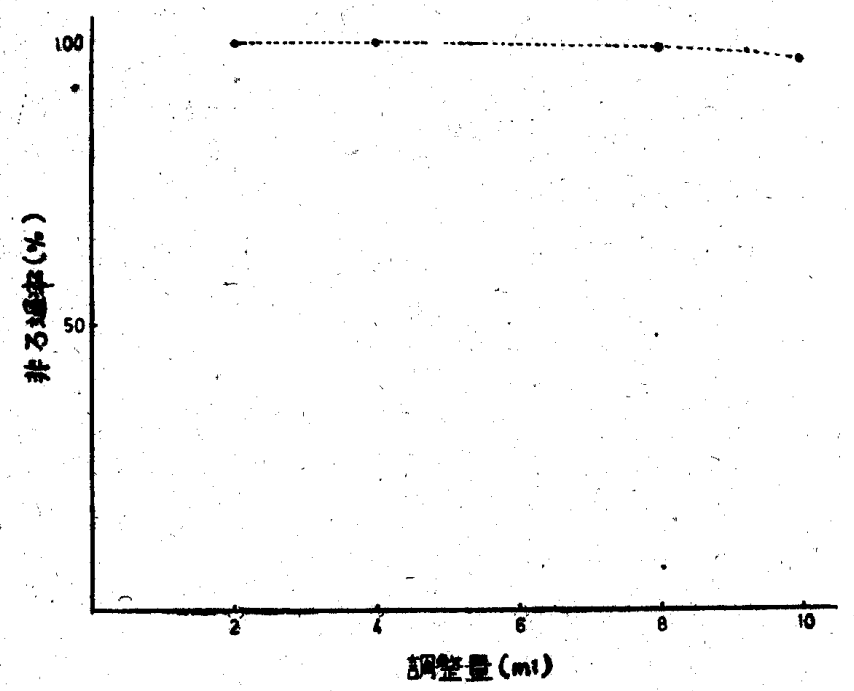

Fig. 3 調整量による非ろ過率

(3) 両コロイドの体内分布

測定結果のうちシンチホトグラム上で肝部に顥著な欠 椇のあるすの等は除き，硫黄コロイド20例, オートバイ アルスズロイド22列について検討した.

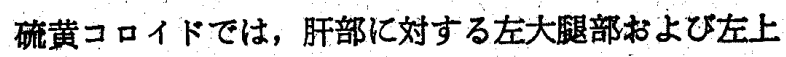
肺部の提取率の平均値はそれぞれ $1.99 \% ， 21.26 \%$ であ った。とれに対しオートバイアルスズコロイドでは大 酿部 $2.76 \%$, 左上肺部 $22.80 \%$ となり硫黄コロイドに比 ベ大きな差はみられない。

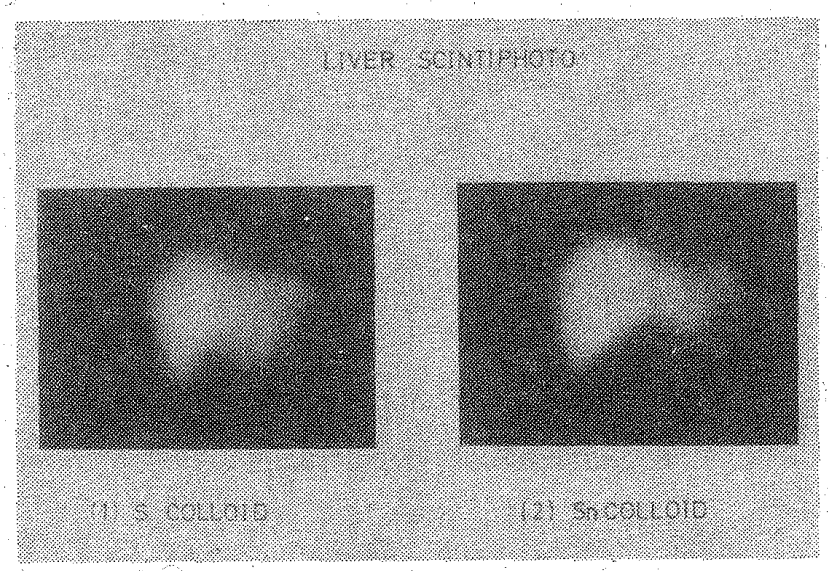

Fig. 4

Fig. 4(1) は硫黄コロイドによる肝の正面像でてのとき の左大煺部および左上肺部の攝取率は各々, $2.11 \%$, 27.37\%である. 又.Fig. 4(2) はオートバイアルスズコロ イドによる肝正面像でてのときの左大殷部, 左上肺部の 摄取率は各々，2.12\%，22.30\%である。

（4）調整時間，被曝その他についての検討

オートバイアルスズコロイドの調整は，

1）ミルキングした ${ }^{99 \mathrm{~m}} \mathrm{TcO}_{4}$ - 溶液を反応バイアルヘ 注入する。

2) オートラベラーにセットする.

3）約10秒間通電する.

以上の三操作で完了する．無菌操作を行っても 5 分以内 亿調整出来る。

これに対し硫黄コロイド(ダイナボット社製 $4 \mathrm{~m} l$ 調 整用）の場合は沸騰水はすでに用意されているすのとし ても次の 6 操作が必要である.

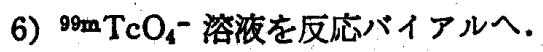

2）試薬（2 種類）を反応バイアルヘ。

3）沸騰水中で 6 分間加熱.

4）試薬を反応バイアルへ.

5）沸騰水中で 3 分間加熱.

6) 室温まで冷却.

調整中の被曝に関しては，平均調整時間を硫黄コロイ ド20分, オートバイアルスズコロイド5分としとれを測 定時間とした。との結果 ${ }^{99 \mathrm{~m}} \mathrm{TcO}_{4}$ - 溶液 $20 \mathrm{mCi}$ 調整時 の被曝は硫黄コロイドは約 $0.08 \mathrm{mR}$ であった。ててれに 対しオートバイアルスズコロイドは約 $0.01 \mathrm{mR} て ゙$ 硫黄 コロイドの約 $1 / 8$ である.

\section{5. 考 …察}

オートバイヌルスズコロイドは調整後 4 時間で非ろ過 率はやや低くなるが，今回の実験結果及び 2 時間以内に 
使用する様に指定されているととを考え合わせると調整 後 2 時間上内に使用する場合は硫黄コロイドに比へ何ら 差はないと思われる。

又オートバイアルスズコロイトの調整量は $4 \mathrm{ml}$ と指

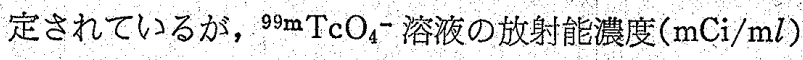
や検查数によっては必ずしもこの量怔適当とはいえない。 我々の実験では調整量 $4 \sim 8 \mathrm{ml}$ の間で非ろ週率の変化は なく従って調整量 $4 \sim 8 \mathrm{ml}$ の間であれば非ろ過率に関し ては調整量を変えてよいといえる.しかし調整量 $10 \mathrm{ml}$ では非ろ過率は低下し又調整量 $2 \mathrm{~m} l$ では調整の際，適 正な電流を流すためにオートラベラーのCURRENT AD J.でかなり大きな補正をしなければならず調整量 $2 \mathrm{ml}$ 及び $10 \mathrm{ml}$ は実用的な調整量ではないと思われる。

オートバイアルスズコロイド交ひ硫黄コロイドの体内 分布については前記結果の外飞各摂取率の静注後の時聞 変化を疾患別に検討したが例数は少ないがとの笛囲では 酥コロイドに差はみられなかった。

調整時間に関してはオートバイアルススコロイドは $99 \mathrm{~m} \mathrm{TcO}_{4}$ - 溶液をこルキングする時からであ約 10 分あれ ば使用可能になるのに対し，硫黄コロイドでは沸滕水の 用意, 無菌操作, 冷却などで時間がかかり作業量, 被曝 の面からあオートバイアルスズコロイドは有益な調整法
そいえる。特に被曝量か硫黄コロイドに比べ極めて少な

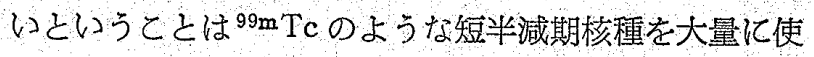
用するようになってきた今日, 被懪軽減の点から非常に 重要なととである.しかし本契験に於ける被曝量測定の 方法は一つの目安であって実際の使用に当っては鉛ブロ ックの使用等,色々な被曝軽減の方法を考えなければな らなしと思う。

\section{6. 結 語}

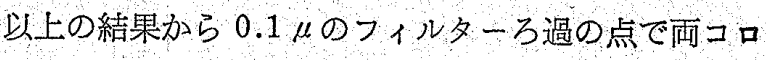
イドに善はないが本実験では粒子サイズの上限は測定さ れていない。しかし，肺，大腿部への集りに差はなく， ンンチホトグラム上でも臨床的に差はなかったので両コ ロイトの大きさの差は実用上殆んどないと思われる。最 大の相哄点はオートバイアルスズコロイドは調整方法が 簡単で, 調整時間が短かくかつ，被曝が少ないととであ る.

患者の被曝を軽減するために が多いが，とのため医療職貝の被曝はむしろ増加してい る.との被曝を軽減するととは現在重要なととなので被 暴量が少なく，しかす診断価値の変らない本コロイド調 整法は高く㟇価されるべきものと思う。 